\title{
ANALISIS MOLEKULER Burkholderia glumae PADA VARIETAS PADI CIHERANG DI SAWAH TADAH HUJAN LINGKUNGAN UNIVERSITAS WIRALODRA INDRAMAYU
}

\author{
Fina Dwimartina ${ }^{1 *}$, Fadhillah Laila $^{2}$ \\ ${ }^{1,2}$ Fakultas Pertanian, Universitas Wiralodra \\ *dwimartinafina@gmail.com
}

\begin{abstract}
Abstrak
Deteksi patogen penyebab penyakit tumbuhan dapat dilakukan baik secara langsung maupun tidak langsung. Deteksi secara langsung umumnya dilakukan dengan menggunakan metode serologi dan molekuler. Deteksi dan identifikasi bakteri patogen dengan teknik molekuler dapat dilakukan dengan teknik polymerase chain reaction (PCR). Penyakit hawar malai yang disebabkan oleh Burkholderia glumae dilaporkan menginfeksi tanaman padi di Indonesia. B. glumae dapat terbawa benih sehingga berpotensi menyebar dengan cepat. Penelitian ini bertujuan untuk mengetahui wilayah sebar penyakit hawar malai di sawah tadah hujan lingkungan Universitas Wiralodra Indramayu. Metode yang dilakukan meliputi pengambilan sampel biji padi Ciherang di sawah tadah hujan lingkungan Universitas Wiralodra Indramayu. Biji padi secara acak diambil langsung dari sawah tadah hujan, kemudian diuji secara molekuler. Penelitian ini dilakukan dalam waktu 12 bulan ketika suhu dan kelembapan tinggi serta menjelang panen pada tanaman padi. B. glumae pada biji padi diekstraksi menggunakan DNeasy Plant Mini Kit Qiagen, dideteksi menggunakan primer Hasebe dan Lida, kemudian dianalisis secara molekuler dengan elektroforesis yang dilakukan terhadap $5 \mu 1$ produk PCR pada agarose $1.2 \%$ di dalam Buffer TAE 1x, pada tegangan $70 \mathrm{~V}$ selama 40 menit. DNA ladder menggunakan 100 bp plus dari Thermo Scientific. Hasil amplifikasi PCR terhadap 3 sampel biji padi menunjukkan ketiga sampel tersebut negatif terinfeksi $B$. glumae. Sampel biji padi yang negatif terdeteksi $B$. glumae dapat terjadi karena pada saat pengambilan sampel, wilayah Indramayu sedang memasuki musim penghujan, sehingga potensi berkembangnya penyakit hawar malai akan menurun.
\end{abstract}

Kata kunci : deteksi, Burkholderia glumae, bulir padi, busuk bulir, molekuler

\begin{abstract}
The detection of plant disease-causing pathogens can be done either directly or indirectly. Direct detection is generally carried out using serological and molecular methods. Detection and identification of pathogenic bacteria with molecular techniques can be done using polymerase chain reaction (PCR) techniques. Panicle blight caused by Burkholderia glumae was reported to infect rice plants in Indonesia. B. glumae can be carried by seeds so that it has the potential to spread quickly. This study aims to determine the distribution area of panicle blight in rainfed rice fields at Wiralodra University, Indramayu. The method used includes sampling Ciherang rice seeds in rainfed rice fields at Wiralodra Indramayu University. Rice seeds were randomly taken directly from rainfed rice fields, then tested molecularly. This research was conducted within 12 months when the temperature and humidity were high and before harvest in rice plants. B. glumae in rice seeds was extracted using DNeasy Plant Mini Kit Qiagen, detected using Hasebe and Lida primers, then analyzed molecularly by electrophoresis which was carried out on $5 \mu$ l of PCR product on $1.2 \%$ agarose in 1x TAE buffer, at a voltage of $70 \mathrm{~V}$ for 40 minutes. . The DNA ladder uses 100 bp plus from Thermo Scientific. The results of PCR amplification of 3 samples of rice seeds showed that the three samples were negative for B. glumae infection. Negative samples of rice seeds detected by B. glumae could occur because at the time of sampling, the Indramayu area was entering the rainy season, so the potential for developing panicle blight disease would decrease.
\end{abstract}

Keyword: detection, Burkholderia glumae, rice grains, grain root, molecular 


\section{Pendahuluan}

Penyakit hawar malai padi disebabkan oleh Burkholderia glumae pertama kali dilaporkan di Jepang tahun 1956, dan diketahui menyebabkan gejala busuk bulir dan hawar pada bibit padi. Menurut Wamishe (2014), gejala ini sering ditemukan pada bulir padi, sehingga dikenal dengan nama busuk bulir (grain rot) di beberapa wilayah Asia. Hawar malai diketahui menjadi salah satu penyakit penting pada pertanaman padi di Amerika, Korea dan Jepang. Pada tahun 1995. penyakit ini mulai berkembang dan menjadi masalah penting pada pertanaman padi di Arkansas, Amerika Serikat. Wilayah ini dikenal sebagai salah satu daerah penghasil padi terbesar di Amerika Serikat. Kehilangan hasil di wilayah Lousiana akibat penyakit hawar malai mencapai 40\% (Mizobuchi et al., 2013).

Menurut Wamishe (2014), pada awalnya penyakit ini sering ditemukan pada tanaman padi kultivar Bengal serta Cypress, dan dikenal dengan dengan nama panicle blight. Gejala yang dihasilkan panicle blight diketahui sebagai akibat dari kondisi lingkungan tertentu, seperti suhu yang tinggi, cekaman air, penyerbukan yang tidak optimal, serta kontaminasi bahan kimia di sekitar perakaran. Kemudian dilakukan isolasi dan identifikasi pada bagian tanaman yang bergejala, untuk mengetahui secara pasti penyebab panicle blight. Hasil identifikasi diketahui bahwa penyebab panicle blight merupakan bakteri patogen tumbuhan Burkholderia glumae. Penamaannya pun berubah menjadi bacterial panicle blight untuk membedakan dengan penyakit yang disebabkan oleh faktor lingkungan karena adanya kemiripan gejala yang dihasilkan (Nandakumar et al., 2009) (Sayler et al., 2006).

Serangan $B$. glumae pada pertanaman padi di Indonesia masih belum sebanyak penyakit hawar daun bakteri oleh Xanthomonas oryzae pv. Oryzae dan penyakit blas oleh Pyricularia oryzae. Kerugian yang disebabkan oleh penyakit hawar malai di Indonesia belum pernah dilaporkan sebelumnya. Namun melihat dari ekologinya, kondisi iklim yang panas dan kering serta curah hujan yang cukup tinggi di Indonesia saat ini sangat sesuai untuk perkembangan penyakit hawar malai. Hal ini tentu akan berpengaruh terhadap peningkatan intensitas serta keparahan penyakit (Joko, 2017). Bakteri patogen ini dapat terbawa benih, sehingga potensi menyebar ke wilayah lain menjadi lebih besar dan dikhawatirkan akan muncul outbreak di masa yang akan datang.

Bakteri B. glumae dapat bertahan pada permukaan tanaman terutama pada bagian daun dan batang pelepah namun bersifat non-patogenik. Koloni bakteri ini dapat tersebar keseluruh bagian tanaman mengikuti pertumbuhan tanaman. Populasi bakteri akan meningkat secara cepat pada permukaan malai yang sedang berkembang dan mulai menginfeksi bunga (Kim et al., 2012). B. glumae akan menginfeksi bulir yang sedang berkembang setelah proses penyerbukan. Bunga padi yang terinfeksi kemudian akan mengalami pembusukan pada saat pengisian bulir (Nandakumar et al., 2009; Tsushima, 1996). Kerentanan terhadap infeksi turun sekitar enam hari setelah tahap pembungaan. Infeksi penyakit hawar malai umumnya berkembang dengan pola melingkar pada suatu pertanaman padi. Pola ini terjadi karena malai yang terinfeksi tetap tumbuh tegak (Takeuchi et al., 1997).

Gejala hawar malai padi dapat terlihat terutama pada bagian malai dan bulir padi. Menurut (Groth dan Hollier, 2009), mulanya gejala berupa bercak kecil berukuran 1-5 mm, berwarna cokelat muda dengan bagian tepi berwarna cokelat. Bercak muncul pada bagian daun, spikelet serta bulir, kemudian pada tingkat infestasi yang tinggi bulir akan gugur sebelum proses pengisian. Bulir padi yang terinfeksi akan menjadi sumber inokulum dan menyebarkan patogen ke bagian malai. Bulir padi yang kosong akan menyebabkan malai tumbuh tegak, namun bagian batang malai tetap berwarna hijau. Bulir padi yang kosong mulanya berwarna kecokelatan, kemudian berubah menjadi keabuan, hitam atau berwarna gelap sebelum akhirnya gugur. Gejala pada bulir yang telah terisi namun terinfeksi $B$. glumae, berupa adanya perubahan warna menjadi cokelat.

Gejala infeksi B. glumae dapat muncul pada bagian pelepah berupa bercak panjang keabuan dengan bagian tepi berwarna cokelat kemerahan. Karakteristik lainnya yaitu malai tumbuh ke atas dan berwarna kekuningan dengan bagian pangkal bunga berwarna gelap serta terdapat garis cokelat kemerahan yang melintang di bagian tengah. Pada tingkat infeksi yang tinggi, proses pengisian bulir dapat terganggu. Hal ini menyebabkan malai tumbuh tegak, karena bulir tidak terisi (Nandakumar et al., 2009).

Tingkat keparahan penyakit hawar malai dipengaruhi oleh beberapa faktor seperti tingkat kerentanan tanaman inang, jumlah inokulum, kelembapan serta kondisi suhu lingkungan (Kado, 2010). Kondisi lingkungan pada tahap pembungaan juga akan menentukan tingkat kejadian dan keparahan penyakit hawar malai. Pada kelembapan tinggi, potensi infeksi bakteri pada bagian spikelet akan meningkat. $B$. glumae akan tumbuh optimal pada suhu $30-35^{\circ} \mathrm{C}$, dan pada kisaran suhu tersebut bakteri ini akan memproduksi senyawa fitotoksin yaitu toxoflavin. Oleh karena itu, penyakit ini sering ditemukan pada daerah tropis dan semi-tropis karena memiliki iklim panas yang cocok untuk perkembangan B. glumae. Selain itu, adanya pemanasan global juga akan meningkatkan kejadian dan keparahan penyakit di pertanaman padi 
(Mizobuchi et al., 2013). B. glumae dapat terbawa benih, sehingga berpotensi tinggi menyebar ke wilayah lain (Yabuuchi et al., 1992).

Deteksi bakteri patogen yang menginfeksi secara laten pada biji atau jaringan tanaman lain cukup sulit dilakukan, karena bakteri target umumnya tersebar secara tidak merata dan dalam populasi yang kecil. Menurut Liu et al. (2012), umumnya metode yang dilakukan untuk mendeteksi dan mengidentifikasi $B$. glumae yaitu secara fisiologi, biokimia, serologi dan molekuler. Deteksi patogen penyebab penyakit tumbuhan dapat dilakukan baik secara langsung maupun tidak langsung. Deteksi secara langsung umumnya dilakukan dengan menggunakan metode serologi dan molekuler. Kedua metode ini dapat digunakan untuk mendeteksi sampel dalam jumlah yang banyak dan menghasilkan analisis yang tepat dan akurat. Metode ini umumnya digunakan untuk mendeteksi mikroorganisme patogen tumbuhan seperti bakteri, virus dan jamur.

Melihat dari ekologinya, kondisi iklim yang panas dan kering serta curah hujan yang cukup tinggi di Indonesia saat ini sangat sesuai untuk perkembangan penyakit hawar malai. Hal ini tentu akan berpengaruh terhadap peningkatan intensitas serta keparahan penyakit. Handiyanti et al (2018) menemukan tanaman padi di Kabupaten Cirebon, Purworejo, dan Banyuwangi terinfeksi patogen ini. Sehingga diperlukan kajian terkait deteksi secara molekuler mengenai penyebaran $B$. glumae di Kecamatan Indramayu sebagai salah satu sentra prosuksi padi nasional yang akan sangat bermanfaat sebagai dasar penentuan tindakan pencegahan dan pengendalian yang preventif bagi patogen tersebut.

\section{Bahan dan Metode}

\section{Pengambilan sampel di lahan}

Percobaan akan dilaksanakan di sawah tadah hujan lingkungan universitas wiralodra Indramayu. Waktu percobaan dilaksanakan selama 12 bulan ketika suhu dan kelembapan tinggi serta menjelang panen pada tanaman padi. Biji padi secara acak diambil di sawah tadah hujan lingkungan universitas wiralodra indramayu.

\section{Ekstraksi dan isolasi DNA B. glumae dari Sampel Biji Padi}

Ekstraksi DNA dari biji/bulir padi menggunakan DNeasy Plant Mini Kit Qiagen. PCR pada sampel menggunakan pasangan primer dari Hasebe and Iida: forward 1418S (5'-GCG ATA TGG CAA GAC GCA AA-3') dan reverse 1418A (5'-AGT CAT ACC CTT TGT CAG CGT-3'), menghasilkan amplikon 571 bp.
Komposisi Komponen PCR (menggunakan MyTaq HS Red Mix PCR, Bioline) dengan komponen Master Mix (2x) $12,5 \mu \mathrm{l}$, Primer forward $(10 \mu \mathrm{M}) 1 \mu \mathrm{l}$, Primer reverse $(10 \mu \mathrm{M}) 1 \mu \mathrm{l}$, Template (DNA) 1-4 $\mu \mathrm{l}$, dan Nuclease Free Water $25 \mu \mathrm{l}$. PCR dilakukan pada mesin Thermocycler AB Verity dengan program: Denaturasi awal 94 C, 4 menit, Amplifikasi 30 siklus: Denaturasi $94^{\circ} \mathrm{C}, 30$ detik, Annealing $59^{\circ} \mathrm{C}, 20$ detik, Ekstensi $72^{\circ}$ C, 45 detik, dan Ekstensi Akhir $72^{\circ} \mathrm{C}, 10$ menit. Elektroforesis dilakukan terhadap $5 \mu 1$ produk PCR pada agarose $1.2 \%$ di dalam Buffer TAE 1x, pada tegangan $70 \mathrm{~V}$ selama 40 menit. DNA ladder menggunakan 100 bp plus dari Thermo Scientific. Setelah selesai elektroforesis, gel agarosa kemudian direndam dalam larutan Ethidium Bromide selama 20 mnt, kemudian dilakukan visualisasi hasil elektroforesis tersebut menggunakan Carestream Gel Logig 212 PRO.

\section{Hasil dan Pembahasan}

Pengambilan sampel biji padi secara acak dilakukan di sawah tadah hujan lingkungan Universitas Wiralodra Indramayu, Jawa Barat. Survei dan pengambilan sampel dilakukan pada bulan Juni Agustus 2020. Sampel biji padi yang diambil memiliki gejala berupa bercak cokelat di bagian permukaan kulitnya. Pada lokasi diperoleh 3 sampel biji padi dengan varietas yang sama, yaitu varietas Ciherang. Varietas tersebut merupakan varietas yang banyak ditanam oleh petani di wilayah Indramayu, karena mampu menghasilkan panen yang cukup tinggi. Selain itu, para petani cenderung menggunakan varietas yang sama selama musim tanam, sehingga jenis padi yang ditanam merupakan varietas dari hasil panen sebelumnya. Pengambilan sampel dilakukan pada saat masa panen hingga setelah masa panen. Hal ini dilakukan untuk mendapatkan sampel berupa malai dan biji padi yang memiliki gejala infeksi $B$. glumae. Biji padi yang terinfeksi akan memiliki gejala bercak cokelat pada bagian permukaan kulitnya. Bercak cokelat dapat muncul baik pada bagian ujung dan pangkal biji maupun melintang di bagian tengah biji. Bercak cokelat tidak hanya terlihat pada bagian permukaan kulit, namun juga pada bagian dalam biji padi yang berwarna putih. Bercak cokelat ini mirip dengan gejala bekas tusukan walang sangit (Leptocorisa oratorius). Baik infeksi B. glumae maupun serangan walang sangit terjadi pada tahap pembungaan hingga tahap masak susu, sehingga bercak cokelat yang terlihat pada permukaan biji seringkali bias dan sulit untuk dibedakan. Gejala infeksi $B$. glumae berupa biji berwana hijau pucat, mengerut, kemudian berubah menjadi kuning dan kecokelatan. Pada awalnya lesi muncul di bagian pangkal biji, kemudian meluas ke bagian atas. Pangkal bulir yang telah terinfeksi lanjut 
akan menjadi busuk dan mengakibatkan aborsi (Sayler et al., 2006). Perbedaan gejala yang disebabkan oleh tusukan hama walang sangit yaitu berupa titik berwarna abu kekuningan dengan warna cokelat di sekeliling bekas tusukan. Biji padi yang terserang, akan menyebabkan separuh hampa, serta beras yang dihasilkan berubah warna menjadi putih kecokelatan hingga kehitaman dan mengapur. Pada proses penggilingan, beras yang telah terserang walang sangit akan menjadi mudah pecah.

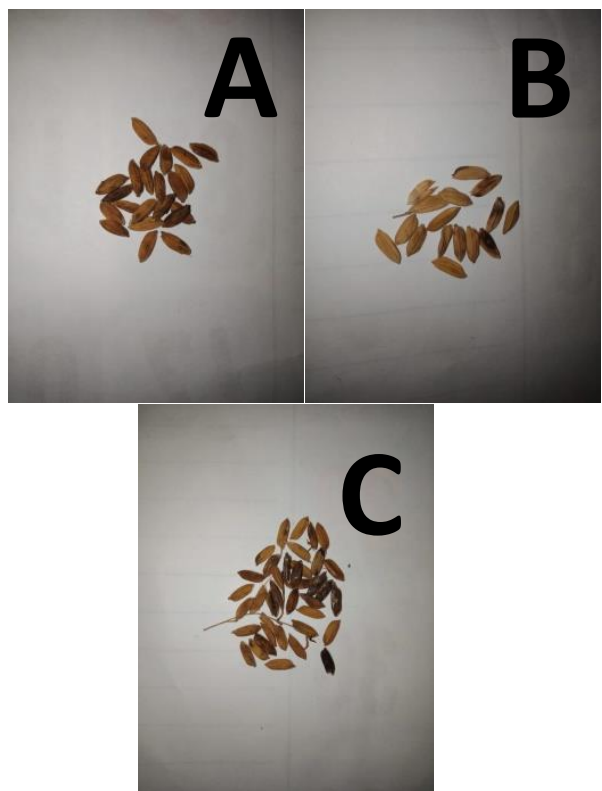

Gambar 1. Varietas sampel biji padi A) Ciherang 1, B) Ciherang 2, dan C) Ciherang 3. Biji padi yang terinfeksi $B$. glumae memiliki ciri bercak cokelat di bagian permukaan kulitnya. Bercak cokelat dapat ditemukan pada bagian uji biji atau melintang di bagian tengah.

Infeksi B. glumae pada tanaman padi lebih banyak terjadi pada bagian bulir. Bakteri B.glumae akan masuk melalui rambut-rambut glume, kemudian mengkolonisasi pada bagian stamen, putik, hingga ovarium bunga padi. Bakteri ini dapat menyebar dan mengganggu proses fertilisasi sehingga tidak terjadi proses pengisian bulir dan mengakibatkan bulir hampa atau aborsi. Jika B. glumae menginfeksi sebelum tahap pembungaan, maka bulir tidak terisi dan mengakibatkan malai tumbuh tegak. Namun bila bakteri ini menginfeksi pada tahap pengisian bulir, maka infeksi tetap terjadi dan B. glumae dapat bertahan pada bulir tersebut (Handiyanti et al., 2018).

B. glumae yang bersifat terbawa benih dapat menurunkan produksi bibit padi. Benih padi yang telah terinfeksi dan membawa $B$. glumae, tidak dapat tumbuh dan berkembang dengan baik. Bibit padi yang tumbuh akan mengalami gejala hawar dan busuk, sehingga tidak dapat dipindah tanamkan. Liu et al., (2012) menyatakan bahwa benih padi yang diberi perlakuan inokulum $B$. glumae, akan mengalami penurunan daya kecambah. Infeksi B. glumae dapat menyebabkan busuk lunak pada masa perkecambahan, selain itu bibit padi yang terinfeksi juga akan tumbuh lebih kecil dan terdapat bercak busuk berwarna cokelat pada bagian pelepah. Infeksi B. glumae di Indonesia dilaporkan hanya terjadi pada tanaman padi. Namun, di beberapa negara telah dilaporkan bahwa bakteri patogen ini juga menginfeksi dan menyebabkan layu bakteri pada tanaman lain seperti tomat, perila, cabai, dan terung (Jeong et al., 2003).

Hasil amplifikasi PCR terhadap 3 sampel biji padi menunjukkan tidak terdapat sampel yang positif terdeteksi B. Glumae (Gambar 2). Ini mengindikasikan sampel yang diambil negatif terinfeksi $B$. glumae. Ketiga sampel tersebut yaitu biji padi varietas Ciherang yang ditanam di sawah tadah hujan lingkungan Universitas Wiralodra Indramayu. Namun, uji konfirmasi dengan isolat bakteri hasil isolasi biji padi juga diperlukan, untuk memastikan hasil yang diperoleh tepat dan akurat. Selain itu, Yabuuchi et al., (1992) menyatakan bahwa deteksi $B$. glumae dapat dilakukan pada sampel benih padi yang diperoleh dari tanaman terinfeksi. Deteksi dilakukan terhadap benih padi dengan gejala berat, ringan serta tanpa gejala.

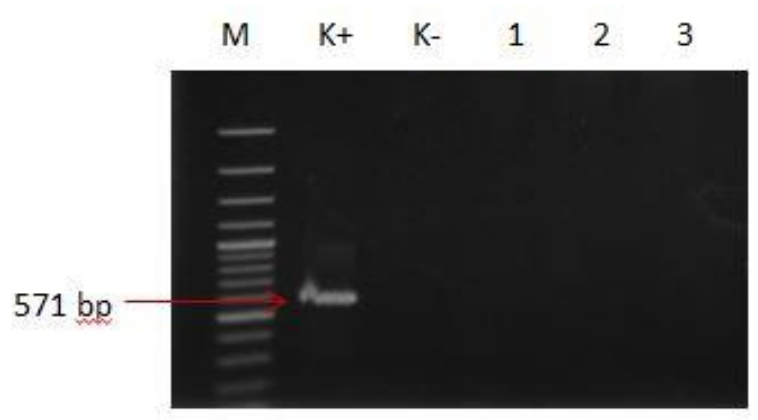

Gambar 2. Visualisasi hasil amplikasi DNA dari varietas padi Ciherang menggunakan primer spesifik. $\mathrm{M}=\mathrm{DNA}$ ladder 100 bp plus; $\mathrm{K}+=$ Kontrol positif (B. glumae); $\mathrm{K}-=$ Kontrol negatif $(\mathrm{NFW}) ; 1=$ Sampel Ciherang 1 ; 2=Sampel Ciherang 2; 3= Sampel Ciherang 3.

Sampel biji padi yang negatif terdeteksi $B$. glumae dapat terjadi karena pada saat pengambilan sampel, wilayah Indramayu sedang memasuki musim penghujan, sehingga potensi berkembangnya penyakit hawar malai akan menurun. Infeksi B. glumae akan meningkat pada suhu dan kelembapan tinggi, sehingga akan berpengaruh terhadap peningkatan insidensi penyakit hawar malai. 


\section{Kesimpulan}

Berdasarkan hasil penelitian, kesimpulan yang diperoleh adalah sebagai berikut:

1. Sampel biji padi yang diambil memiliki gejala berupa bercak cokelat dibagian permukaan kulitnya. Bercak cokelat ditemukan pada bagian pangkal, yang semakin meluas ke bagian tengah biji.

2. Hasil amplifikasi PCR terhadap 3 sampel biji padi menunjukkan tidak terdapat sampel yang positif terdeteksi B. Glumae.

3. Sampel biji padi yang negatif terdeteksi $B$. glumae dapat terjadi karena pada saat pengambilan sampel, wilayah Indramayu sedang memasuki musim penghujan, sehingga potensi berkembangnya penyakit hawar malai akan menurun.

\section{Ucapan Terimakasih}

Ucapan terima kasih disampaikan kepada Universitas Wiralodra dan Lembaga Penelitian dan Pengabdian Kepada Masyarakat (LPPM) Universitas Wiralodra selaku pemberi dana melalui hibah internal Universitas Wiralodra beserta Laboratorium Balai Besar Uji Standar Karantina Pertanian yang telah melakukan pengujian terhadap sampel bulir padi sehingga Kami dapat menyelesaikan penelitian ini.

\section{Daftar Pustaka}

Groth, D. \& C. Hollier. 2009. Rice diseases of Louisiana. Lousiana State University Agricultural Center Publising 3084 (5M) 01/09.

Handiyanti, M., Subandiyah, S., Joko, T. 2018. Molecular detection of Burkholderia glumae, a causal agent of bacterial panicle blight disease. JPTI. 22(1):98-107. DOI: https://doi.org/10.22146/jpti.30259.

Jeong Y., J. Kim, S. Kim, Y. Kang, T. Nagamatsu, \& I Hwang. 2003. Toxoflavin produced by Burkholderia glumae causing rice grain rot is reposible for inducing bacterial wilt in many field crops. Plant Disease. 87:890895.

Joko, T. 2017. Burkholderia glumae sebagai emerging pathogen: Status, potensi kerusakan, dan strategi pengedalian. Prosiding Simposium Nasional Fitopatologi, p. 27-35.

Kado, C. I. 2010. Plant Bacteriology. Minnesota: APS Press.

Kim, B.K., M. S. Cho, M. H. Kim, H. J Choi, M. J. Kang, \& H. S. Shim. 2012. Rapid and specific detection of Burkholderia glumae in rice seed by Real-Time Bio-PCR using specific-specific primers based on an rhs family gene. Plant Disease: 96:577-580.

Liu, W., L. Li, M. A. Khan, \& F. Zhu. 2012. Popular molecular markers in bacteria. Molecular genetics, Microbiology and Virology 27:103-107.

Mizobuchi, R., H. Sato, S. Fukuoka, T. Tanabata, S. Tsushima, T. Imbe, \& M. Yano. 2013. Mapping a quantitative trait locus for resistance to bacterial grain rot in rice. Rice 6:13.

Nandakumar, R., A.K.M. Shahjahan, X.L. Yuan, E.R. Dickstein, D.E. Groth, C.A. Clark, R.D. Cartwright, \& M.C. Rush. 2009. Burkholderia glumae and B. gladioli cause bacterial panicle blight in rice in the Southern United States. Plant Disease. 93:896-905

Sayler, R.J., R.D. Cartwright, \& Y. Yang. 2006. Genetic characterization and realtime PCR detection of Burkholderia glumae, a newly emerging bacterial pathogen of rice in the United States. Plant Disease 90:603-610.

Takeuchi, T., H. Sawada, F. Suzuki, \& I. Matsuda. 1997. Specific detection of Burkholderia plantarii and B. glumae by PCR using primers selected from the 16S-23S rDNA spacer regions. Annals of the Phytopathological Society of Japan 63:455-462.

Tsushima, S. 1996. Epidemiology of bacterial grain rot of rice caused by Pseudomonas glumae. Japan Agricultural Research Quarterly 30: 85-89.

Wamishe, Y. 2014. Bacterial panicle blight of rice. Forum for Agricultural Risk Management in Development. http://www.agriskmanagementforum.org /content/bacterial-panicle-blight-rice.

Yabuuchi, E., Y. Kosako, H. Oyaizu, I. Yano, H. Hotta, Y. Hashimoto, T. Ezaki, \& M. Arakawa. 1992. Proposal of Burkholderia gen. nov. and transfer of seven species of the genus Pseudomonas homology group II to the new genus, with the type species Burkholderia cepacia (Palleroni and Holmes 1981) comb. nov. Microbiology and Immunology 36:1251 -1275. 